\title{
Pharmacologic Management of Malignant Bowel Obstruction: When Surgery Is Not an Option
}

\author{
Kevin Hsu, MD'; Eric Prommer, MD, FAAHPM, HMDC ${ }^{2,3}$; Mary C Murphy, MD², , Azadeh Lankarani-Fard, MD,5*
}

'Department of Internal Medicine, Cedars-Sinai Medical Center, Los Angeles, California; ${ }^{2}$ Palliative Care Division, VA Greater Los Angeles Healthcare System, Los Angeles, California; ${ }^{3}$ David Geffen School of Medicine, University of California Los Angeles, Los Angeles, California. ${ }^{4} \mathrm{Hospitalist}$ Division, VA Greater Los Angeles Healthcare System, Los Angeles, California; ${ }^{5}$ Department of Medicine, Hospitalist Division, David Geffen School of Medicine, University of California Los Angeles, Los Angeles, California.

Malignant bowel obstruction (MBO) complicates 3\%-15\% of cancers and often necessitates inpatient admission. Hospitalists are increasingly involved in treating patients with $\mathrm{MBO}$ and coordinating their care across multiple subspecialties. Direct resolution of the obstruction via surgical or interventional means is always preferable. When such options are not possible, pharmacological treatments are the mainstay of therapy. Medications such as somatostatin analogs, steroids, $\mathrm{H} 2$-blockers, and other modalities can be effective in palliation and possible resolution of obstruction. Awareness of these pharmacologic therapies can aid hospitalists in treating patients who are confronted with this devastating condition. Journal of Hospital Medicine 2019;14:367-373. Published online first April 8, 2019. @ 2019 Society of Hospital Medicine

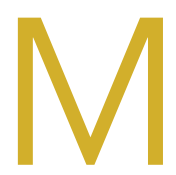
alignant bowel obstruction (MBO) is a catastrophic complication of cancer that often requires hospitalization and a multidisciplinary approach in its management. Hospitalists frequently collaborate with such specialties as Hematology/Oncology, Surgery, Palliative Medicine, and Interventional Radiology in arriving at a treatment plan.

Initial management is focused on hydration, bowel rest and decompression via nasogastric (NG) tube. Surgical resection or endoscopic stenting should be considered early. ${ }^{1}$ However, patients who present in the terminal stages may be poor candidates for these options due to diminished functional status, multiple areas of obstruction, complicated anatomy limiting intervention, or an associated large volume of ascites.

Presence of inoperable MBO portends a poor prognosis, often measured in weeks. ${ }^{2}$ Presentation often occurs in the context of a sentinel hospitalization, signifying a shift in disease course. ${ }^{3,4}$ It is essential for hospitalists to be familiar with noninvasive therapies for inoperable MBO given the increasing role of hospitalists in providing inpatient palliative care. Palliative pharmacologic management of MBO can reduce symptom burden during these terminal stages and will be the focus of this paper.

\section{BACKGROUND AND PATHOPHYSIOLOGY}

Malignant bowel obstruction occurs in about $3 \%-15 \%$ of patients with cancer. ${ }^{2} \mathrm{~A}$ consensus definition of $\mathrm{MBO}$ established

\footnotetext{
*Corresponding Author: Azadeh Lankarani-Fard, MD; E-mail:azadeh.lankarani-fard@va.gov; Telephone: 310-478-3711
}

Received: August 21, 2019; Revised: January 17, 2019;

Accepted: February 2, 2019

(C) 2019 Society of Hospital Medicine DOI 10.12788/jhm.3187 the following specific criteria: (1) clinical evidence of bowel obstruction, (2) obstruction distal to the ligament of Treitz, and (3) the presence of primary intra-abdominal cancer with incurable disease or extra-abdominal cancer with peritoneal involvement. ${ }^{5}$ The most common malignancies are gastric, colorectal, and ovarian in origin. ${ }^{1,2}$ The most common extra-abdominal malignancies associated with MBO are breast, melanoma, and lung. MBO is most frequently diagnosed during the advanced stages of cancer. ${ }^{2}$ The obstruction can involve a partial or total blockage of the small or large intestine from either an intrinsic or extrinsic source. Peristalsis may also be impaired via direct tumor infiltration of the intestinal walls or within the enteric nervous system or celiac plexus. Other etiologies of $\mathrm{MBO}$ include peritoneal carcinomatosis and radiation-induced fibrosis. ${ }^{1,6}$ The obstruction can occur at a single level or involve multiple areas, which usually precludes surgical intervention. ${ }^{2}$

Symptoms of MBO can be insidious in onset and take several weeks to manifest. The most prevalent symptoms are nausea, vomiting, constipation, abdominal pain, and distension. 2,6 The intermittent pattern of symptoms may evolve into continuous episodes with spontaneous remission in between. The etiology of symptoms can be attributed to distension proximal to the site of obstruction with concomitantly increased gastrointestinal and pancreaticobiliary secretions.

The distension creates a "hypertensive state" in the intestinal lumen causing enterochromaffin cells to release serotonin which activates the enteric nervous system and its effectors including substance $P$, nitric oxide, acetylcholine, somatostatin, and vasoactive intestinal peptide (VIP). These neurotransmitters stimulate the secretomotor actions that cause hypersecretion of mucus from cells of the intestinal crypts. Additional water and sodium secretions accumulate due to the expanded surface area of the bowel. ${ }^{1,2}$ Overloaded with luminal contents, the bowel attempts to overcome the obstruction by contracting, which 


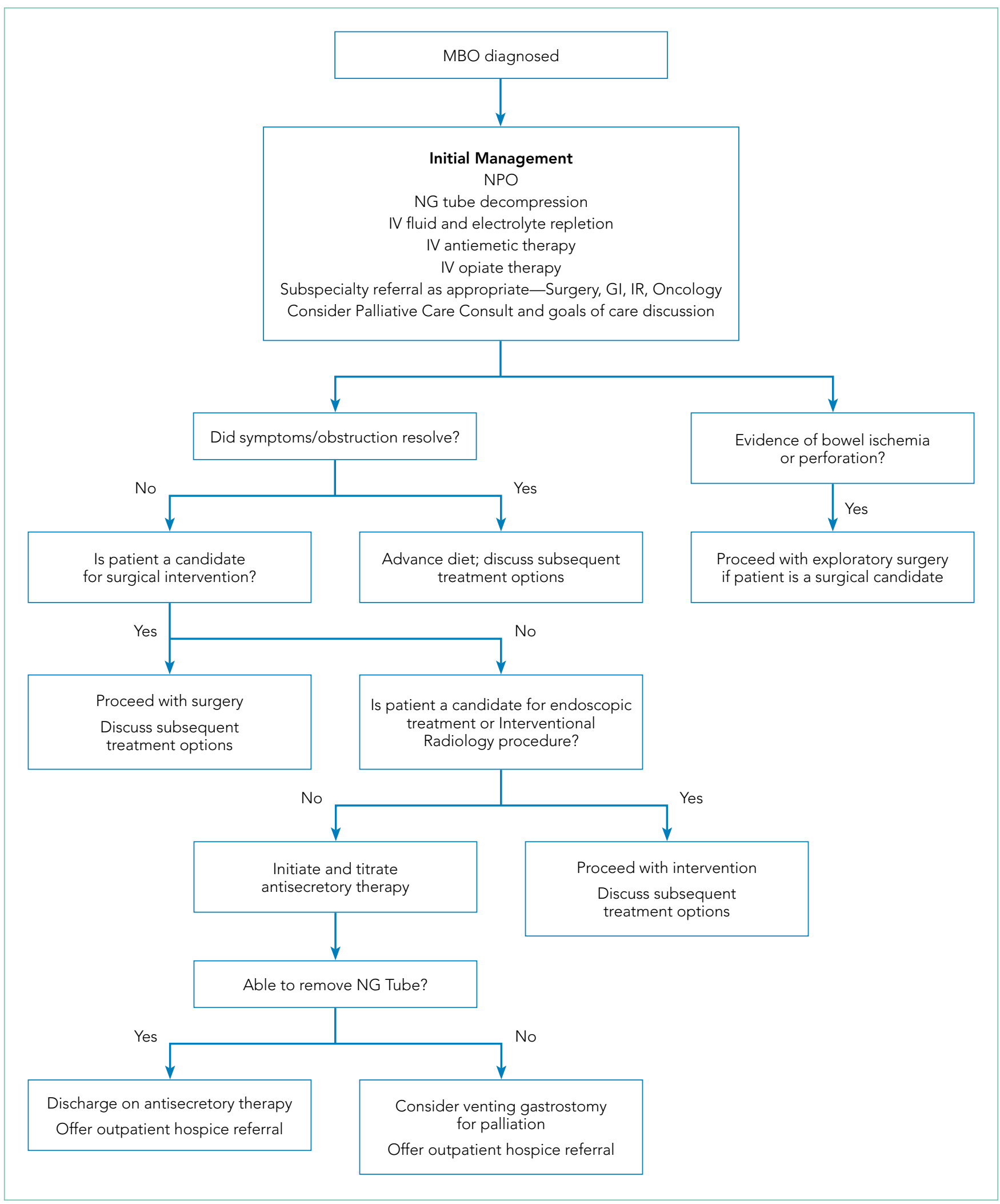

FIG. Management Algorithm for Malignant Bowel Obstruction

Abbreviations: GI, gastroenterology; IR, interventional radiology; IV, intravenous; MBO, malignant bowel obstruction; NG, nasogastric; NPO, nil per os (ie, nothing by mouth). 
leads to colicky abdominal pain. Tumor burden can also damage the intestinal epithelium and cause continuous pain.

The buildup of secretions can lead to translocation of fluid into the peritoneum ("third spacing"), bowel ischemia, perforation, or sepsis. The combination of poor oral intake, gastrointestinal fluid loss, and sequestration can lead to profound dehydration on presentation..$^{2,7}$

\section{INITIAL MANAGEMENT}

Fluid resuscitation, electrolyte repletion, and a trial of NG tube decompression are part of the initial management of MBO (Figure 1). While studies have shown that moderate intravenous hydration can minimize nausea and drowsiness, excessive fluids may worsen bowel edema and exacerbate vomiting. ${ }^{1,8} \mathrm{NG}$ tube decompression is most effective in patients with proximal obstructions but some studies suggest it can decrease vomiting in patients with colonic obstructions as well. ${ }^{9}$ Computed tomography imaging can identify the extent of the tumor, the transition point of the obstruction, and any distant metastases. Surgery, Gastroenterology, and/or Interventional Radiology consultation should be obtained early to evaluate options for direct decompression. Hematology/ Oncology and Radiation/Oncology referral may help delineate prognosis and achievable outcomes. Emergent exploratory surgery may be required in cases of bowel perforation or ischemia. Otherwise, a planned surgical resection should be considered in those with an isolated resectable lesion and acceptable perioperative risk. Colorectal or duodenal stents may be an option for those who are not surgical candidates or as a bridge to surgery.

As bowel obstruction is often a late manifestation of advanced malignancy, many patients may not be appropriate candidates for operative/interventional treatment due to malnutrition, comorbid conditions, or anatomic considerations. For these individuals, pharmacologic management is the mainstay of treatment. Additionally, the pharmacologic approaches detailed below may provide benefit as adjunctive therapy for patients undergoing procedural intervention. ${ }^{7}$ Consultation for early palliative care can improve symptom control as well as clarify goals of care.

\section{PHARMACOLOGIC MANAGEMENT}

Given the pathophysiology of MBO, pharmacologic therapies are focused on controlling nausea and pain while reducing bowel edema and secretions.

\section{Antiemetic Agents}

Nausea and vomiting in $\mathrm{MBO}$ are due to activation of vagal nerve fibers in the gastric wall and stimulation of the chemoreceptor trigger zone (CTZ). ${ }^{10}$ Dopamine antagonists have started to gain favor for MBO compared to more commonly used antiemetics such as the serotonin antagonists. Haloperidol should be considered as a first-line antiemetic in patients with $\mathrm{MBO}$. Its potent $D_{2}$-receptor antagonistic properties block receptors in the CTZ. The high affinity of the drug for only the $D_{2}$-receptor makes it preferable to alternative agents in the same class such as chlorpromazine. However, haloperidol may cause or worsen QT prolongation and should be avoided in patients with Parkinson's disease. The medication has less sedative and unwanted anticholinergic side effects due to its limited interaction with histaminergic and acetylcholine receptors. ${ }^{11}$ Haloperidol has been shown in the past to be efficacious for post-operative nausea but there are few randomized controlled trials in the terminally ill. ${ }^{12}$ Nonetheless, recent consensus guidelines from the Multinational Association of Supportive Care recommended haloperidol as the initial treatment of nausea for individuals with $\mathrm{MBO}$ based on available systematic reviews. ${ }^{10}$

Other dopamine antagonists remain good options, though they may cause additional side effects due to actions on other receptor types. Metoclopramide, another $\mathrm{D}_{2}$-receptor antagonist, has been shown to be effective in the treatment of nausea and vomiting due to advanced cancer. ${ }^{13}$ However as a prokinetic agent, this medication should be avoided in those with complete $\mathrm{MBO}$ and only considered in those with partial MBO. ${ }^{10,14}$

Olanzapine, an atypical antipsychotic, may also have a role in controlling nausea in patients with $\mathrm{MBO}$. It functions as a $5-\mathrm{HT}_{2 \mathrm{~A}}$ and $\mathrm{D}_{2}$-receptor antagonist, with a slightly greater affinity for the $5-\mathrm{HT}_{2 \mathrm{~A}}$ receptor. Olanzapine thus can target two critical receptors playing a role in nausea and vomiting. A study of patients with incomplete bowel obstruction found the addition of olanzapine significantly decreased nausea and vomiting in patients who were refractory to other treatments including steroids and haloperidol. ${ }^{15}$ Olanzapine has the added advantage of single-day dosing as well as an oral disintegrating formulation. ${ }^{16}$

Intravenous and sublingual preparations of $5-\mathrm{HT}_{3}$ receptor antagonists such as ondansetron are commonly used in the inpatient setting. These medications are potent antiemetics that exhibit their effects via pathways where serotonin acts as a neurotransmitter. ${ }^{17}$ An alternative agent, tropisetron, has shown promise when used alone or in conjunction with metoclopramide but is not currently available in the US. ${ }^{18}$ Granisetron is available in a transdermal formulation, which can be very convenient for patients with bowel obstruction. Its mechanism of action differs from ondansetron as it is an allosteric inhibitor rather than a competitive inhibitor. ${ }^{19}$ Granisetron needs more specific study with regards to its role in $\mathrm{MBO}$.

Although haloperidol remains the initial choice, combination therapy can help to decrease the risk of extrapyramidal symptoms seen with higher doses of dopaminergic monotherapy.

\section{Analgesics}

Pain control is an essential part of the palliative treatment of $\mathrm{MBO}$ as bowel distention, secretions, and edema can cause rapid onset of pain. Parenteral step three opioids remain the optimal initial choice since patients are unable to take medications orally and may have compromised absorption. Opioids address both the colicky and continuous aspects of MBO pain.

Short-acting intravenous opioids such as morphine or hydromorphone may be scheduled every four hours with breakthrough dosing every hour in between. Alternatively, analgesics 
TABLE 1. Summary of Preferred Pharmacologic Agents for Malignant Bowel Obstruction

\begin{tabular}{|c|c|c|c|}
\hline & Class & Preferred Agents/Dosage & Comments \\
\hline First-line & \multirow[t]{3}{*}{ Somatostatin analogs } & \multirow{3}{*}{$\begin{array}{l}\text { Octreotide initial dose } 100 \mathrm{mcg} \text { SC tid-qid with titration to effect } \\
(\max 1 \mathrm{mg} / \text { day })^{7,12}\end{array}$} & 1.Expensive \\
\hline \multirow[t]{7}{*}{ Antisecretory } & & & 2.Benefit apparent in first 3 days (range $1-5 d$ ) \\
\hline & & & 3.Collaboration with palliative medicine recommended with dose titration \\
\hline & Combination Therapy: & Steroid: & 1. Combination is noninferior to somatostatin analogues ${ }^{38}$ \\
\hline & Steroids + & Dexamethasone IV total $8 \mathrm{mg} /$ day in one dose $\mathrm{e}^{38}$ & 2. PPI's not as well studied but have significant antisecretory effect ${ }^{33}$ \\
\hline & \multirow[t]{3}{*}{ PPI/ H2-blockers } & H2-blockers & \\
\hline & & Ranitidine $50 \mathrm{mg}$ IV qid & \\
\hline & & Pantoprazole $40 \mathrm{mg}$ IV qd & \\
\hline \multirow{2}{*}{$\begin{array}{l}\text { Second-line } \\
\text { Antisecretory }\end{array}$} & \multirow[t]{2}{*}{ Anticholinergic agents } & Glycopyrrolate $0.1-0.2$ mg IV or SC q6 -8 hours $^{39}$ & \multirow{2}{*}{$\begin{array}{l}\text { 1. Scopolamine butylbromide not equivalent to scopolamine hydrobromide } \\
\text { (available in US) }\end{array}$} \\
\hline & & Scopolamine butylbromide 20-120 mg/day IV/IM' (not available in US) & \\
\hline \multirow[t]{8}{*}{ Adjunct therapies } & \multirow[t]{4}{*}{ Antiemetics } & Haloperidol $0.5 \mathrm{mg}$ IV/SC tid-qid, up to $5 \mathrm{mg} / 24$ hours & \multirow[t]{4}{*}{ 1. Metoclopramide should be avoided in cases of complete obstruction. } \\
\hline & & Olanzapine 2.5-7.5 mg po daily (oral disintegrating) ${ }^{16}$ & \\
\hline & & Ondansetron 4-8 mg sublingual or IV & \\
\hline & & Metoclopromide 5-10 mg IV/SC qid prn & \\
\hline & \multirow[t]{4}{*}{ Analgesics } & Dosages will vary across patients. & 1. Consider PCA \\
\hline & & For opioid-naïve patients: & \multirow[t]{3}{*}{ 2. Collaboration with palliative medicine recommended with dose titration } \\
\hline & & Morphine $1 \mathrm{mg}$ IV/SC q4hr PRN & \\
\hline & & Hydromorphone 0.2 mg IV/SC q4hr PRN & \\
\hline
\end{tabular}

Abbreviations: IM, intramuscular; IV, intravenous; PCA, patient-controlled analgesia; PPI, proton pump inhibitor; po, per os (ie, by mouth); PRN, pro re nata (ie, as needed); SC, subcutaneous.

can be administered via a patient-controlled analgesia (PCA) pump. ${ }^{1}$ Although doses vary across patients, opioid-naïve patients can be initiated on a low dose therapy such as hydromorphone $0.2 \mathrm{mg}$ IV/SC or morphine $1 \mathrm{mg}$ IV/SC every four hours as needed for pain control.

Ongoing pain management for patients with $\mathrm{MBO}$ requires coordination of care. Many patients will elect to receive hospice care following discharge. Direct communication with palliative consultants and hospice providers can help facilitate a smooth transition. In patients for whom bowel obstruction resolves, transition to oral opioids based on morphine equivalent daily dose is indicated with further dose adjustment as patients may have reduced pain at this stage.

Options for patients with unresolved obstruction include transdermal and sublingual preparations as well as outpatient PCA with hospice support. Transdermal fentanyl patch can be useful but onset of peak levels occur within 8-12 hours. ${ }^{20}$ The patch is usually exchanged every 72 hours and is most effective when applied to areas containing adipose tissue which may limit its use in cachectic patients. The liquid preparation of methadone can be useful even in patients with unresolved $\mathrm{MBO}$. Its lipophilic properties allow for ease of absorption. ${ }^{21}$ A baseline electrocardiogram (EKG) is recommended prior to methadone initiation due to the potential for QT prolongation. Methadone should not be a first-line option for opioid-naïve individuals due to its longer onset of action which limits rapid dose titration. Close collaboration with palliative medicine is highly recommended when using longer acting opioids.

\section{Antisecretory Agents}

Antisecretory agents are a mainstay of the pharmacologic management of inoperable MBO. Medications that reduce secretions and bowel edema include: somatostatin analogs, H2-blockers, proton pump inhibitors (PPIs), steroids, and anticholinergic agents. Table 2 summarizes the major studies comparing various antisecretory medications.

Octreotide, a somatostatin analog, has been increasingly used for the palliative treatment of MBO. The mechanism of action involves splanchnic vasoconstriction, reduction of intestinal and pancreatic secretions (via inhibition of VIP), decrease in gastric emptying, and slowing of smooth muscle contractions. ${ }^{22}$ Octreotide comes in an immediate-release formulation with an initial subcutaneous dose of $100 \mu \mathrm{g}$ three or four times per day. Most patients will require 300-800 $\mu \mathrm{g} /$ day, maximum dose being up to $1 \mathrm{mg} /$ day. ${ }^{22,23} \mathrm{~A}$ long-acting formulation, lanreotide, exists but can be difficult to obtain and may not provide the immediate relief needed in an acute care setting.

Initiation of octreotide should be considered in the presence of persistent symptoms. Studies have suggested that the benefit of octreotide is most apparent in the first three days of treatment (range 1-5 days). $6,22,24$ The medication should be discontinued if there is no clinical improvement such as reduction of NG tube output. Octreotide has been shown to be more efficacious than anticholinergic agents in reducing secretions as well as frequency of nausea and vomiting. ${ }^{8,25-28}$ Octreotide expedites NG tube removal, recovery of bowel function, and improvement in quality of life. ${ }^{29-32}$ The medication should also 
TABLE 2. Summary of Major Clinical Trials Comparing the Efficacies of Antisecretory Agents for Malignant Bowel Obstruction

\begin{tabular}{|c|c|c|c|c|c|}
\hline Study & Patient Population & Intervention & Comparison & $\begin{array}{l}\text { Primary } \\
\text { Outcome }\end{array}$ & Summary of Findings \\
\hline $\begin{array}{l}\text { Currow et al. } \\
(2015)^{38}\end{array}$ & $\begin{array}{l}87 \text { patients with inoperable } \\
\text { MBO on IV dexamethasone } \\
(8 \mathrm{mg} / 24 \text { hours })+\text { ranitidine } \\
(200 \mathrm{mg} / 24 \text { hours }) \pm \text { IV fluids } \\
(10-20 \mathrm{~cm} 3 / \mathrm{kg} / \text { day })\end{array}$ & $\begin{array}{l}\text { Octreotide }(600 \mu \mathrm{g} / 24 \text { hours }) ; \\
n=45\end{array}$ & Placebo; $n=42$ & $\begin{array}{l}\text { Number of days } \\
\text { free of vomiting } \\
72 \text { hours after } \\
\text { administration }\end{array}$ & $\begin{array}{l}\text { No statistically significant difference in number } \\
\text { of days free of vomiting }(P=.71) \text {. }\end{array}$ \\
\hline $\begin{array}{l}\text { Peng et al. } \\
(2015)^{25}\end{array}$ & $\begin{array}{l}96 \text { patients with inoperable MBO } \\
\text { due to ovarian cancer. Concomitant } \\
\text { treatment in both groups: NGT, } \\
\text { IV fluids }\end{array}$ & $\begin{array}{l}\text { Octreotide }(300 \mu \mathrm{g} / 24 \text { hours); } \\
\mathrm{n}=48\end{array}$ & $\begin{array}{l}\text { Scopolamine butylbromide } \\
\text { ( } 60 \mathrm{mg} / 24 \text { hours); } n=49\end{array}$ & $\begin{array}{l}\text { Measured NGT } \\
\text { secretions; } \\
\text { number of } \\
\text { vomiting episodes } \\
\text { at each day for } 72 \\
\text { hours }\end{array}$ & $\begin{array}{l}\text { Significant reduction in NGT secretions and number } \\
\text { of vomiting episodes at each day in the octreotide } \\
\text { group }(P<.05) \text {. }\end{array}$ \\
\hline \multirow[t]{4}{*}{$\begin{array}{l}\text { Mariani et al. } \\
(2012)^{32}\end{array}$} & \multirow{4}{*}{$\begin{array}{l}80 \text { patients with inoperable MBO } \\
\text { due to peritoneal carcinomatosis } \\
\text { with continued symptoms after } \\
\text { treatment with steroids and PPI. }\end{array}$} & $\begin{array}{l}\text { Double-blind phase: ( } 10 \text { days): } \\
\text { lanreotide ( } 30 \mathrm{mg} \text { on day } 1) ; \\
n=43\end{array}$ & \multirow[t]{4}{*}{ Placebo; $n=37$} & \multirow{4}{*}{$\begin{array}{l}\text { Proportion of } \\
\text { patients with one } \\
\text { or fewer vomiting } \\
\text { episodes at day } \\
7 \text { or no vomiting } \\
\text { recurrence after } \\
\text { NGT removal }\end{array}$} & $\begin{array}{l}\text { No statistically significant difference achieving } \\
\text { primary outcome in intention to treat analysis } \\
(41.9 \% \text { vs } 29.7 \% ; P=.24)\end{array}$ \\
\hline & & \multirow{3}{*}{$\begin{array}{l}\text { Open-label phase: lanreotide } \\
\text { (every } 10 \text { days until treatment } \\
\text { cessation); } n=59\end{array}$} & & & $\begin{array}{l}\text { Significant decrease in symptoms in per protocol } \\
\text { analysis }(57 \% \text { vs. } 30.4 \% \mathrm{P}<.05)\end{array}$ \\
\hline & & & & & Significant response in investigators assessment: \\
\hline & & & & & No effect on NG tube removal. \\
\hline $\begin{array}{l}\text { Laval et al. } \\
(2012)^{31}\end{array}$ & $\begin{array}{l}64 \text { patients with inoperable MBO } \\
\text { due to peritoneal carcinomatosis } \\
\text { Concomitant treatment in both } \\
\text { groups: methylprednisolone } \\
\text { 3-4 mg/kg/day on days 1-6 }\end{array}$ & $\begin{array}{l}\text { Octreotide ( } 600 \mu \mathrm{g} / 24 \text { hours) } \\
\text { on days } 1-6+\text { octreotide LAR } \\
(30 \mathrm{mg}) \text { on days } 1,29,57 \\
n=32\end{array}$ & Placebo; $n=32$ & $\begin{array}{l}\text { Proportion of } \\
\text { patients with } \\
\text { treatment success } \\
\text { at day 14, defined } \\
\text { as: absence of } \\
\text { NGT and vomiting } \\
<2 \text { times per day } \\
\text { and no use of } \\
\text { anticholinergics }\end{array}$ & $\begin{array}{l}\text { Treatment success for octreotide group compared } \\
\text { to placebo arm ( } 38 \% \text { vs. } 28 \%)(38 \%) \text { Treatment } \\
\text { success more apparent in those with Karnofsky } \\
\text { score }>50:(60 \% \text { vs. } 28 \%) \text { and those without NGT } \\
\text { at onset ( } 53 \% \text { vs } 33 \%) \text {. }\end{array}$ \\
\hline \multirow[t]{2}{*}{$\begin{array}{l}\text { Mystakidou et al. } \\
(2002)^{27}\end{array}$} & $\begin{array}{l}68 \text { with advanced cancer and } \\
\text { diagnosed with bowel obstruction }\end{array}$ & $\begin{array}{l}\text { Octreotide }(600-800 \mu \mathrm{g} / 24 \\
\text { hours); } \mathrm{n}=34\end{array}$ & \multirow{2}{*}{$\begin{array}{l}\text { Scopolamine butylbromide } \\
(60-80 \mathrm{mg} / 24 \text { hours })) ; \\
n=34\end{array}$} & \multirow{2}{*}{$\begin{array}{l}\text { Mean percentage } \\
\text { change in } \\
\text { vomiting episodes; } \\
\text { nausea scores at } \\
\text { day } 0,3,6 \text {, and } 1 \\
\text { day before death }\end{array}$} & \multirow{2}{*}{$\begin{array}{l}\text { Significant mean percentage reduction in vomiting } \\
\text { episodes and nausea scores in the octreotide group } \\
\text { between day } 0 \text { and } 3(P<.05) \text {. }\end{array}$} \\
\hline & $\begin{array}{l}\text { Concomitant treatment in both } \\
\text { groups: chlorpromazine } \\
\text { (15-25 mg/24 hours) }\end{array}$ & & & & \\
\hline $\begin{array}{l}\text { Mercadante et al. } \\
(2000)^{26}\end{array}$ & 18 patients with inoperable MBO & $\begin{array}{l}\text { Octreotide ( } 300 \mu \mathrm{g} / 24 \text { hours); } \\
\mathrm{n}=9\end{array}$ & $\begin{array}{l}\text { Scopolamine butylbromide } \\
\text { ( } 60 \mathrm{mg} / 24 \text { hours); } n=6\end{array}$ & $\begin{array}{l}\text { Reduction in } \\
\text { vomiting episodes } \\
\text { at each day } \\
\text { for } 72 \text { hours }\end{array}$ & $\begin{array}{l}\text { Significant reduction in mean vomiting episodes } \\
\text { in the octreotide group mostly noted on day } 1 \\
\text { and } 2 \text { after administration }-2(P<0.01 ; P<.004 \text {, } \\
\text { respectively). }\end{array}$ \\
\hline $\begin{array}{l}\text { Ripamonti et al. } \\
(2000)^{8}\end{array}$ & 17 patients with inoperable MBO & $\begin{array}{l}\text { Octreotide }(300 \mu \mathrm{g} / 24 \text { hours }) ; \\
n=9\end{array}$ & $\begin{array}{l}\text { Scopolamine butylbromide } \\
\text { ( } 60 \mathrm{mg} / 24 \text { hours); } n=8\end{array}$ & $\begin{array}{l}\text { Daily volume of } \\
\text { NGT secretions } \\
\text { at each day } \\
\text { for } 72 \text { hours }\end{array}$ & $\begin{array}{l}\text { Significant reduction in NGT secretions in the } \\
\text { octreotide group at days } 2-3(P=.016 \text { and } \\
P=.020 \text {, respectively). }\end{array}$ \\
\hline
\end{tabular}

Abbreviations: IV, intravenous; MBO, malignant bowel obstruction; NGT, nasogastric tube; PPI, proton pump inhibitor.

be considered in cases of recurrent $\mathrm{MBO}$ that previously responded to the medication.

Octreotide is considered the first-line agent in the palliative treatment of $\mathrm{MBO}$, however the medication is costly. Recent studies suggest combination therapy with steroids and $\mathrm{H} 2$-blockers or PPIs may be an equally effective and less expensive alternative. The primary rationale for the use of steroids in $\mathrm{MBO}$ is their ability to decrease peritumoral edema and promote salt and water absorption from the intestine. ${ }^{1,2} \mathrm{PPIs}$ and $\mathrm{H} 2$-blockers decrease distension, pain, and vomiting by reducing the volume of gastric secretions. ${ }^{33} \mathrm{~A}$ recent meta-analysis of phase 3 trials found both PPIs and H2-blockers to be effective in lowering volumes of gastric aspirates with ranitidine being slightly superior. ${ }^{34}$

Initial research into the utility of steroids in MBO garnered mixed results. One study showed marginal benefit for steroid plus octreotide combination therapy compared to octreotide, in a cohort of 27 patients. ${ }^{35} \mathrm{~A}$ subsequent review of practice patterns in the management of terminal MBO in Japan found that patients given steroids in combination with octreotide compared to octreotide alone were more likely to undergo early NG tube removal. ${ }^{36} \mathrm{~A} 1999$ systematic review of corticosteroid treatment of MBO concluded low morbidity associated with the medications with a trend toward benefit that was not statistically significant. ${ }^{37} \mathrm{~A} 2015$ study by Currow showed the addition of octreotide in patients already on a regime of dexamethasone and ranitidine did not improve the number of days free from vomiting but did reduce vomiting episodes in those with the most refractory symptoms. ${ }^{38}$

Collectively, the studies suggest that combination therapy 
with steroid and PPI or $\mathrm{H} 2$ blocker could be a less expensive option in the initial management of MBO. Alternatively, steroids may provide additional relief in patients with continued symptoms on octreotide and H2-blockers. Dexamethasone is preferable given its longer half-life and decreased propensity for sodium retention. Dosing of dexamethasone should be 8 mg IV once a day. ${ }^{38}$

Anticholinergic agents also reduce secretions. However, they are considered second-line therapy given their lower efficacy compared to other treatment options as well as their propensity to worsen cognitive function. ${ }^{1,2}$ Anticholinergics may benefit patients with continued symptoms who cannot tolerate the side effects of other treatments. Scopolamine, also known as hyoscine hydrobromide in the US, should be avoided as it crosses the blood-brain barrier. The quaternary formulation, scopolamine butylbromide (hyoscine butylbromide), does not pass this barrier but is currently not available in the US. Glycopyrrolate may be considered as it is also a quaternary ammonium compound that does not cross the blood-brain barrier. Several case reports have described its effectiveness in the resolution of refractory nausea and vomiting in combination with haloperidol and hydromorphone for symptom control. ${ }^{39}$ Effective oral care is imperative if anticholinergics are used in order to prevent the unpleasant feeling of dry mouth.

\section{SUBSEOUENT SUPPORTIVE CARE}

While initial management of $\mathrm{MBO}$ often requires placement of an NG tube, prolonged placement can increase the risk for erosions, aspiration, and sinus infections. Removal of the NG tube is most successful when secretions are minimal, but this may not happen unless the obstruction resolves. Some patients may elect to keep an NG tube if symptoms cannot be otherwise controlled by medications.

A venting gastrostomy tube can be considered as an alternative to prolonged NG tube placement. The tube may help alleviate distressing symptoms and can enhance the quality of life of patients by allowing the sensation of oral intake, though it will not allow for absorption of nutrients. ${ }^{40}$ Although a low risk procedure, patients may be too frail to undergo the procedure and may have postprocedure pain and complications. Anatomic abnormalities such as overlying bowel may also prevent the noninvasive percutaneous approach.

In patients with unresolved obstruction, oral intake should be reinitiated with caution with the patient's wishes taken into account at all times. Some patients may prioritize the comfort derived from eating small amounts over any associated risks of increased nausea and vomiting.

Parenteral nutrition should be avoided in those with inoperable $\mathrm{MBO}$ in the advanced stages. The risks of infection, refeeding syndrome, and the discomfort of an intravenous line and intermittent testing may outweigh any benefits given the overall prognosis. ${ }^{41,42}$

\section{CONCLUSION}

Hospitalists are often involved in the initial care of patients with advanced malignancy who present with $\mathrm{MBO}$. When interven- tions or surgeries to directly alleviate the obstruction are not possible, pharmacologic options are essential in managing burdensome symptoms and improving quality of life. Early Palliative Care referral can also assist with symptom management, emotional support, clarification of goals of care, and transition to the outpatient setting. While patients with inoperable MBO have a poor prognosis, hospitalists can play a vital role in alleviation of suffering in this devastating complication of advanced cancer.

Disclosures: The authors have nothing to disclose.

\section{References}

1. Ripamonti $\mathrm{Cl}$, Easson AM, Gerdes H. Management of malignant bowel obstruction. Eur J Cancer. 2008;44(8):1105-1115. doi: 10.1016/j.ejca.2008.02.028.

2. Tuca A, Guell E, Martinez-Losada E, Codorniu N. Malignant bowel obstruction in advanced cancer patients: epidemiology, management, and factors influencing spontaneous resolution. Cancer Manag Res. 2012;4:159-169. doi: 10.2147/CMAR.S29297.

3. Meier DE. Palliative care in hospitals. J Hosp Med. 2006;1(1):21-28. doi: 10.1002/jhm.3.

4. Lin RJ, Adelman RD, Diamond RR, Evans AT. The sentinel hospitalization and the role of palliative care. J Hosp Med. 2014;9(5):320-323. doi: 10.1002/ jhm.2160.

5. Anthony T, Baron T, Mercadante S, et al. Report of the clinical protocol committee: development of randomized trials for malignant bowel obstruction. J Pain Symptom Manage. 2007;34(1 Suppl):S49-S59. doi: 10.1016/j.jpainsymman.2007.04.011.

6. Laval G, Marcelin-Benazech B, Guirimand F, et al. Recommendations for bowel obstruction with peritoneal carcinomatosis. J Pain Symptom Manage. 2014;48(1):75-91. doi: 10.1016/j.jpainsymman.2013.08.022.

7. Ferguson $\mathrm{HJ}$, Ferguson $\mathrm{Cl}$, Speakman J, Ismail T. Management of intestinal obstruction in advanced malignancy. Ann Med Surg. 2015;4(3):264-270. doi: 10.1016/j.amsu.2015.07.018.

8. Ripamonti C, Mercadante S, Groff L, et al. Role of octreotide, scopolamine butylbromide, and hydration in symptom control of patients with inoperable bowel obstruction and nasogastric tubes: A prospective randomized trial. J Pain Symptom Manage. 2000;19(1):23-34. doi: 10.1016/S0885-3924(99)00147-5.

9. Rao W, Zhang X, Zhang J, et al. The role of nasogastric tube in decompression after elective colon and rectum surgery: a meta-analysis. Int J Colorectal Dis. 2011;26(4):423-429. doi: 10.1007/s00384-010-1093-4.

10. Walsh D, Davis M, Ripamonti C, et al. 2016 updated MASCC/ESMO consensus recommendations: management of nausea and vomiting in advanced cancer. Support Care Cancer. 2017;25(1):333-340. doi: 10.1007/s00520-0163371-3.

11. Murray-Brown F, Dorman S. Haloperidol for the treatment of nausea and vomiting in palliative care patients. Cochrane Database Syst Rev. 2015;11(11): CD006271. doi: 10.1002/14651858.CD006271.pub3.

12. Digges M, Hussein A, Wilcock $A$, et al. Pharmacovigilance in hospice/palliative care: Net effect of haloperidol for nausea or vomiting. J Palliat Med. 2018;21(1):37-43. doi: 10.1089/jpm.2017.0159.

13. Bruera E, Belzile M, Neumann C, et al. A double-blind, crossover study of controlled-release metoclopramide and placebo for the chronic nausea and dyspepsia of advanced cancer. J Pain Symptom Manage. 2000;19(6):427-435. doi: 10.1016/S0885-3924(00)00138-X.

14. Gupta M, Davis M, LeGrand S, Walsh D, Lagman R. Nausea and vomiting in advanced cancer: the Cleveland clinic protocol. J Support Oncol. 2013;11(1):8-13. doi: 10.1016/j.suponc.2012.10.002.

15. Kaneishi K, Kawabata M, Morita T. Olanzapine for the relief of nausea in patients with advanced cancer and incomplete bowel obstruction. J Pain Symptom Manage. 2012;44(4):604-607. doi: 10.1016/j.jpainsymman.2011.10.023.

16. Prommer E. Olanzapine: palliative medicine update. Am J Hosp Palliat Care. 2013;30(1):75-82. doi: 10.1177/1049909112441241.

17. Currow DC, Coughlan M, Fardell B, Cooney NJ. Use of ondansetron in palliative medicine. J Pain Symptom Manage. 1997;13(5):302-307. doi: 10.1016/ S0885-3924(97)00079-1.

18. Mystakidou K, Befon S, Trifyllis J, Liossi C, Papadimitriou J. Tropisetron versus metoclopramide in the control of emesis in far-advanced cancer. Oncologist. 1997;2(5):319-323. doi: 10.1007/s11136-005-4324-3 
19. Tuca A, Roca R, Sala C, et al. Efficacy of granisetron in the antiemetic control of nonsurgical intestinal obstruction in advanced cancer: A phase II clinical trial. J Pain Symptom Manage. 2009;37(2):259-270. doi: 10.1016/j.jpainsymman.2008.01.014.

20. Prommer E. The role of fentanyl in cancer-related pain. J Palliat Med. 2009;12(10):947-954. doi: 10.1089/jpm.2009.0051.

21. Shaiova LL, Berger A, Blinderman CD, et al. Consensus guideline on parenteral methadone use in pain and palliative care. Palliat Support Care. 2008;6(2):165-176. doi: 10.1017/S1478951508000254.

22. Murphy E, Prommer EE, Mihalyo M, Wilcock A. Octreotide. J Pain Symptom Manage. 2010;40(1):142-148. doi: 10.1016/j.jpainsymman.2010.05.002.

23. Prommer EE. Established and potential therapeutic applications of octreotide in palliative care. Support Care Cancer. 2008;16(10):1117-1123. doi: 10.1007/s00520-007-0399-4.

24. Mercadante S, Ferrera P, Villari P, Marrazzo A. Aggressive pharmacological treatment for reversing malignant bowel obstruction. J Pain Symptom Manage. 2004;28(4):412-416. doi: 10.1016/j.jpainsymman.2004.01.007.

25. Peng $X$, Wang P, Li S, Zhang G, Hu S. Randomized clinical trial comparing octreotide and scopolamine butylbromide in symptom control of patients with inoperable bowel obstruction due to advanced ovarian cancer. World $\mathrm{J}$ Surg Oncol. 2015;13:50. doi: 10.1186/s12957-015-0455-3.

26. Mercadante S, Ripamonti C, Casuccio A, Zecca E, Groff L. Comparison of octreotide and hyoscine butylbromide in controlling gastrointestinal symptoms due to malignant inoperable bowel obstruction. Support Care Cancer. 2000;8(3):188-191. doi: 10.1007/s005200050283.

27. Mystakidou K, Tsilika E, Kalaidopoulou O, et al. Comparison of octreotide administration vs conservative treatment in the management of inoperable bowel obstruction in patients with far advanced cancer: a randomized, double-blind, controlled clinical trial. Anticancer Res. 2002;22(2B):1187-1192.

28. Obita GP, Boland EG, Currow DC, Johnson MJ, Boland JW. Somatostatin analogues compared with placebo and other pharmacologic agents in the management of symptoms of inoperable malignant bowel obstruction: a systematic review. J Pain Symptom Manage. 2016;52(6):901-919. doi: 10.1016/j. jpainsymman.2016.05.032.

29. Watari H, Hosaka M, Wakui $Y$, et al. A prospective study on the efficacy of octreotide in the management of malignant bowel obstruction in gynecologic cancer. Int J Gynecol Cancer. 2012;22(4):692-696. doi: 10.1097/IGC Ob013e318244ce93.

30. Hisanaga T, Shinjo T, Morita T, et al. Multicenter prospective study on efficacy and safety of octreotide for inoperable malignant bowel obstruction. Jpn J Clin Oncol. 2010;40(8):739-745. doi: 10.1093/jjco/hyq048.
31. Laval G, Rousselot H, Toussaint-Martel S, et al. SALTO: a randomized, multicenter study assessing octreotide LAR in inoperable bowel obstruction. Bull Cancer. 2012;99(2):E1-E9. doi: 10.1684/bdc.2011.1535.

32. Mariani PP, Blumberg J, Landau A, et al. Symptomatic treatment with lanreotide microparticles in inoperable bowel obstruction resulting from peritoneal carcinomatosis: a randomized, double-blind, placebo-controlled phase III study. J Clin Oncol. 2012;30(35):4337-4343. doi: 10.1200/JCO.2011.40.5712.

33. Clark K, Lam L, Currow D. Reducing gastric secretions--a role for histamine 2 antagonists or proton pump inhibitors in malignant bowel obstruction? Support Care Cancer. 2009;17(12):1463-1468. doi: 10.1007/s00520-009-0609-3.

34. Strand DS, Kim D, Peura DA. 25 years of proton pump inhibitors: a comprehensive review. Gut Liver. 2017;11(1):27-37. doi: 10.5009/gnl15502.

35. Murakami $H$, Matsumoto $H$, Nakamura M, Hirai T, Yamaguchi Y. Octreotide acetate-steroid combination therapy for malignant gastrointestinal obstruction. Anticancer Res. 2013;33(12):5557-5560.

36. Minoura T, Takeuchi M, Morita T, Kawakami K. Practice patterns of medications for patients with malignant bowel obstruction using a nationwide claims database and the association between treatment outcomes and concomitant use of H2-blockers/proton pump inhibitors and corticosteroids with octreotide. J Pain Symptom Manage. 2018;55(2):413-419. doi: 10.1016/j. jpainsymman.2017.10.019

37. Feuer DJ, Broadley KE. Systematic review and meta-analysis of corticosteroids for the resolution of malignant bowel obstruction in advanced gynaecological and gastrointestinal cancers. Systematic Review Steering Committee. Ann Oncol. 1999;10(9):1035-1041. doi: 10.1023/A:1008361102808.

38. Currow DC, Quinn S, Agar M, et al. Double-blind, placebo-controlled, randomized trial of octreotide in malignant bowel obstruction. J Pain Symptom Manage. 2015;49(5):814-821. doi: 10.1016/j.jpainsymman.2014.09.013.

39. Davis MP, Furste A. Glycopyrrolate: a useful drug in the palliation of mechanical bowel obstruction. J Pain Symptom Manage. 1999;18(3):153-154.

40. Zucchi E, Fornasarig M, Martella L, et al. Decompressive percutaneous endoscopic gastrostomy in advanced cancer patients with small-bowel obstruction is feasible and effective: a large prospective study. Support Care Cancer. 2016;24(7):2877-2882. doi: 10.1007/s00520-016-3102-9.

41. Naghibi M, Smith TR, Elia M. A systematic review with meta-analysis of survival, quality of life and cost-effectiveness of home parenteral nutrition in patients with inoperable malignant bowel obstruction. Clin Nutr. 2015;34(5):825-837. doi: 10.1016/j.clnu.2014.09.010.

42. O'Connor B, Creedon B. Pharmacological treatment of bowel obstruction in cancer patients. Expert Opin Pharmacother. 2011;12(14):2205-2214. doi: $10.1517 / 14656566.2011 .597382$ 